\title{
Influence of climate change on phenological phases in Latvia and Lithuania
}

\author{
${\text { Gunta Kalvāne }{ }^{1, *} \text {, Danuta Romanovskaja }{ }^{2} \text {, Agrita Briede }{ }^{1} \text {, Eugenija Bakšienè }}^{2}$ \\ ${ }^{1}$ University of Latvia, Faculty of Geography and Earth Sciences, Raina Blvd. 19, Rīga 1059, Latvia \\ ${ }^{2}$ Voke Branch of Lithuanian Institute of Agriculture, Zalioji a. 2, Vilnius 02232, Lithuania
}

\begin{abstract}
To investigate the impact of recent climatic changes on plant development, this study used phenological data of the volunteer networks in Latvia and Lithuania from the 1971-2000 period. The phenological calendar method was applied. Phenological seasons were described using data on 6 phenological phases at 10 stations. The growing season was described using birch Betula pendula as an example. Correlation analysis, linear regression and non-parametric Mann-Kendall trend tests were applied to establish the relationship between phenological phases and meteorological factors (temperature, precipitation) and the North Atlantic Oscillation (NAO). The results indicate a statistically significant trend toward earlier onset of spring and summer phases. The study found that, unlike the majority of trends observed in Europe, on average the onset of phenological autumn in Latvia and Lithuania also started earlier. The observed trends in spring correlated well with temperatures in the preceding months and with the NAO. A strong correlation (in 12 cases out of 20) was found between spring phenophases and precipitation in February.
\end{abstract}

KEY WORDS: Phenology $\cdot$ Climate change $\cdot$ Phenological trends · Time series $\cdot$ Growing season

\section{INTRODUCTION}

Phenological information is important in monitoring all aspects of ecosystems in agricultural, medicine, forestry, tourism and wildlife management (Beaubien \& Freeland 2000). As phenological rhythms are closely related to climate, phenological phases can play the role of climate change indicators. Phenology is probably the simplest and most cost-effective means of observing the effects of changes in temperature; consequently, phenology has become an important tool in the research of global climatic change.

The origin of phenology can be traced back to ancient society, but the oldest existing phenological record is from Japan: the flowering of cherry has been observed and recorded since $705 \mathrm{AD}$. In Europe, the oldest time series, dating back to 1370, consists of the ripening of grapes in France (Chuine et al. 2004). In the Baltic States, the longest phenological data series was reconstructed for rye harvest in Estonia and dates back to the 17th century (Ahas 1999). The first phenological observations in
Lithuania were made at the end of the 18th century, but the first phenological network was developed in 1959. In Latvia, the first observations date to 1822 , whereas the phenological network has operated since 1926.

Numerous studies from around the world have shown significant changes in the onset of phenological phases during the 20th century (Ahas 1999, Ahas et al. 2002, Bradley et al. 1999, Harrington et al. 1999, Menzel 2000, 2003, Bogaert et al. 2002, Root et al. 2003, Linderholm 2006, Zheng et al. 2006). For example, it was found that in north and northeastern China and the lower reaches of the Huaihe River, phenophases advanced 1.1 to $4.3 \mathrm{~d}$ per decade for early spring and 1.4 to $5.4 \mathrm{~d}$ per decade for late spring, but in the eastern part of southwest China they were delayed by 2.9 to $6.9 \mathrm{~d}$ per decade for early spring and 2.4 to $6.2 \mathrm{~d}$ per decade for late spring (Zheng et al. 2006). A study in Wisconsin, USA, for the period 1976-1998 showed that several phenological events have been increasingly early. The average regression for the 55 phenophases studied was $-0.12 \mathrm{~d}$ per year (Bradley et al. 1999). 
In Europe, based on International Phenological Gardens data (1959-1996), spring events such as leaf unfolding have advanced an average of $6.3 \mathrm{~d}(-0.21 \mathrm{~d}$ per year), while autumn events such as leaf colouring have been delayed by $4.5 \mathrm{~d}$ ( $0.15 \mathrm{~d}$ per year). Combining these, the average annual growing season has extended by $10.8 \mathrm{~d}$ since the early 1960s (Menzel 2000). According to Ahas et al. (2002), in the period 1951-1998, spring phases have advanced by $4 \mathrm{wk}$ in Western and Central Europe and by up to $2 \mathrm{wk}$ in Eastern Europe.

In Estonia, the onset of spring has advanced by $8 \mathrm{~d}$ over the last $80 \mathrm{yr}$, with a faster change occurring over the last 40 yr (Ahas 1999). In Lithuania, phenological spring started 8 to $16 \mathrm{~d}$ earlier at the end of the 20th century than in the late 70s (Romanovskaja \& Bakšienè 2007). Over the last $50 \mathrm{yr}$, the beginning of spring and summer phases in Latvia has shifted earlier by $4 \mathrm{~d}$ (Grisule \& Briede 2007).

The aim of the present study is to characterize the variability of the phenological time series for the 19712000 period and to assess the impact of climate change on phenology in Latvia and Lithuania.

\section{MATERIALS AND METHODS}

\subsection{Phenological database}

The present study is based on volunteer-collected phenological data in Latvia and Lithuania, at sites located between $54^{\circ} 40^{\prime}$ and $57^{\circ} 23^{\prime} \mathrm{N}$ and $21^{\circ} 01^{\prime}$ and $27^{\circ} 31^{\prime} \mathrm{E}$ (Fig. 1).

With respect to plant development under different climate conditions, the territory of Lithuania is divided into 3 phenoclimatic regions. Phenological stations (Fig. 1) were chosen to represent all phenoclimatic regions of the country: Traku Voke (Aukstaiciai region), Silute (Zemaiciai Upland) and Akademija, Papile and Keturvalakiai (West Zemaiciai Plain and Central Lithuanian Plain; subdivided into 3 subregions).

The number of phenological stations in Latvia varied from year to year and there were gaps in the data series as well. Based on the data quality and quantity, we selected data from 5 phenological stations for the present study; at 2 of these sites (Atasiene-Barkava and LiepajaNica) the data series from nearby stations were combined. Unlike Lithuania, Latvia's territory is not divided into phenoclimatic regions, but into physiogeographic regions, which are distinguished by different geomorphological and climate conditions.

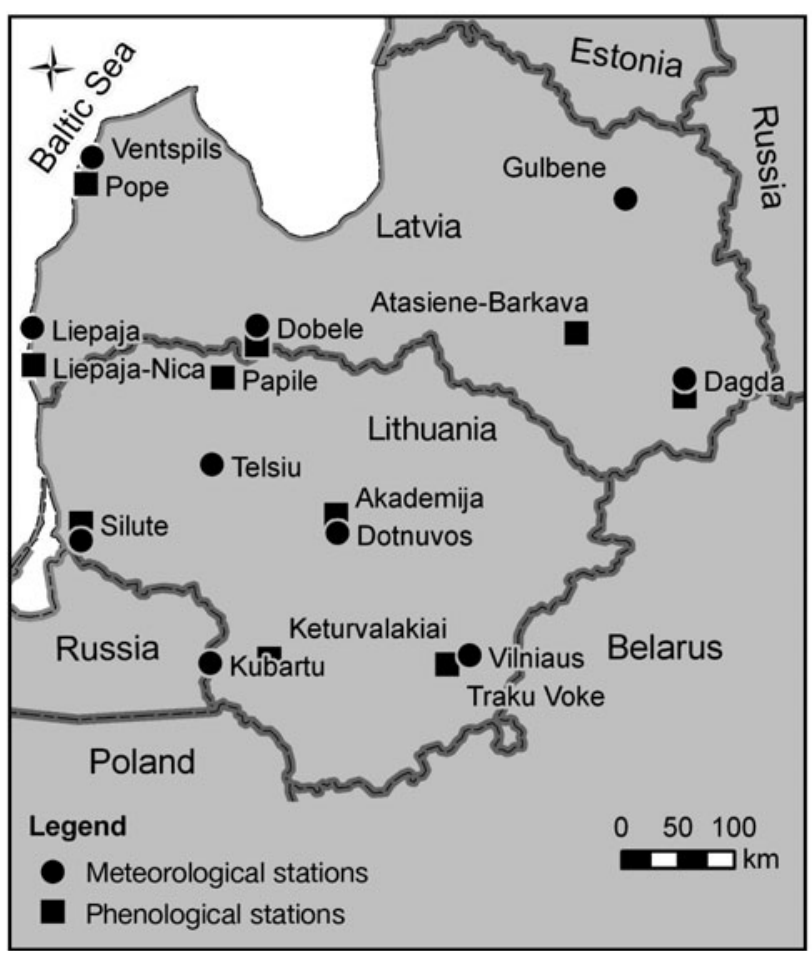

Fig. 1. Location of phenological and meteorological stations in Latvia and Lithuania used in the present study

Seasonal changes were studied using onset dates of phenological seasons. According to V. Köppen classification (McKnight \& Hess 2004), Latvia and Lithuania are located in the humid continental climate zone; therefore, plant indicators denoting the beginning of phenological phases common to both countries were chosen. The choice of plants as season indicators (Table 1) was made based on the division of indicator plants commonly used in Europe and choosing those most suitable for the climate zone of Lithuania and Latvia (Kulienè \& Tomkus 1990).

Table 1. Indicators for the phenological and growing seasons. Bundesanstalt, Bundessortenamt and Chemical Industry $(\mathrm{BBCH})$ scale classifies the entire development cycle of plants into 10 principal phases (0-9) and 10 secondary stages (0-9) as a 2-digit number. For details see Meier (1997)

\begin{tabular}{|c|c|c|c|}
\hline & Species & Phase & BBCH code \\
\hline \multicolumn{4}{|c|}{ Phenological season } \\
\hline Spring & $\begin{array}{c}\text { Alnus incana } \\
\text { Corylus avellana }\end{array}$ & Beginning of flowering & 61 \\
\hline Summer & $\begin{array}{c}\text { Philadelphus coronarius } \\
\text { Syringa vulgaris }\end{array}$ & Beginning of flowering & 61 \\
\hline Autumn & $\begin{array}{l}\text { Betula pendula } \\
\text { Acer platanoides }\end{array}$ & Leaf colouring & 92 \\
\hline \multicolumn{4}{|c|}{ Growing season } \\
\hline Start & Betula pendula & Beginning of leafing & 11 \\
\hline End & Betula pendula & Leaf colouring & 92 \\
\hline
\end{tabular}


The phenological dates refer to the day of the year and phenological phases are in Bundesanstalt, Bundessortenamt and Chemical Industry (BBCH) codes. The extended BBCH-scale is a system for a uniform coding of phenologically similar growth stages of all mono- and dicotyledonous plant species. The entire developmental cycle of the plants is subdivided into 10 clearly recognizable and distinguishable longer-lasting developmental phases (Meier 1997).

\subsection{Meteorological database}

Climate data (monthly temperature and precipitation) for the years 1971-2000 were obtained from the Latvian Environment, Geology and Meteorology Agency and from the Lithuanian Hydrometeorological Service.

Meteorological stations were selected at locations close to the phenological stations with the exception of 2 sites, Atasiene-Barkava and Papile, located within $50 \mathrm{~km}$ northeast and south, respectively, from the closest meteorological station (Fig. 1). We consider the microclimate differences between these sites and the meteorological stations to be small.

Monthly indices for the NAO were taken from the NOAA Climate Prediction Centre web page (www. cpc.noaa.gov/index.php).

\subsection{Methods}

Data were manually checked and outliers were excluded from the data series if the difference in the beginning of phenophases among the closest phenological stations was larger than 1 mo. Data quality was verified by using the 3-sigma method: 3-sigma is a statistical boundary representing plus or minus 3 standard deviations from a measure of central tendency (i.e. mean) for a group of values.

For the study of time series we used the following analytical tools: regression analysis, correlation analysis and non-parametric Mann-Kendall (M-K) test analysis. Phenological data were statistically described by calculating the mean, standard error and coefficient of variation (Dospehov 1973).

The main statistical parameters were drawn from the regression analysis. The mean temporal change (days per year) of the studied variables was evaluated using the regression slopes. The purpose of using the M-K test (Libiseller \& Grimvall 2002) for trend detection is to determine the sign of all pairwise differences between the consecutive elements of time series, while each of them is compared with all previous values in the time series. The M-K test is non-parametric and does not require the data be distributed normally. It is not sensitive to abrupt breaks due to non-homogeneous time series, which are characteristic of phenological records (Libiseller \& Grimvall 2002). The test statistic is near zero when the number of positive and negative differences is more or less equal. There is an increasing trend if the test statistic is positive, i.e. the number of positive differences is significantly higher than the number of negative differences, and vice versa. The result was considered to be statistically significant if the value of the normalised M-K test statistic was $>1.65$ or $<-1.65$, with $p<0.05$.

Correlation analysis was applied to investigate the relationship between phenological time-series and temperature, precipitation and NAO. Correlation coefficients $>0.36$ or $<-0.36$ were considered as statistically significant for the $30-y r$ period with $\mathrm{p}<0.05$.

\section{RESULTS}

In general, the character of changes in air temperature and precipitation for the 1971-2000 period was similar for Latvia and Lithuania. Trend analysis of spring (March-May) temperature changes according to the $\mathrm{M}-\mathrm{K}$ test demonstrated statistically significant increases for all stations $(\mathrm{M}-\mathrm{K}>1.92, \mathrm{p}<0.05)$. At the same time, examining monthly temperature data showed significant increases only in April (M-K > 1.97, $\mathrm{p}<0.05)$. The mean temperature of autumn 1971-2000 changed neither in Latvia nor Lithuania. Precipitation in Latvia and Lithuania had a high spatial variability influenced by peculiarities of local landscape, topography and distance from the Baltic Sea. The highest totals of monthly precipitation within the studied period were measured in August at the stations lying near the Baltic Sea coast - $291 \mathrm{~mm}$ in Silute (1978) and $281 \mathrm{~mm}$ in Liepaja (1972) — while in August 1996 and 1997 at most of the stations located in the remote inland areas, zero or very low precipitation $(<10 \mathrm{~mm})$ was recorded. Results show a statistically significant increase in the amount of precipitation in Latvia and Lithuania only in February (9 of 10 stations) and January ( 7 of 10 stations).

\subsection{Patterns of the phenological seasons}

According to phenological observation data of the years 1971-2000, the spring season indicators European hazel Corylus avellana and grey alder Alnus incana flowered in Lithuania and Latvia from the 3rd decad (10 d period) of March through to the 1st decad of April (Fig. 2).

In both Baltic countries, European hazel started flowering earlier than grey alder. In Lithuania, which is 


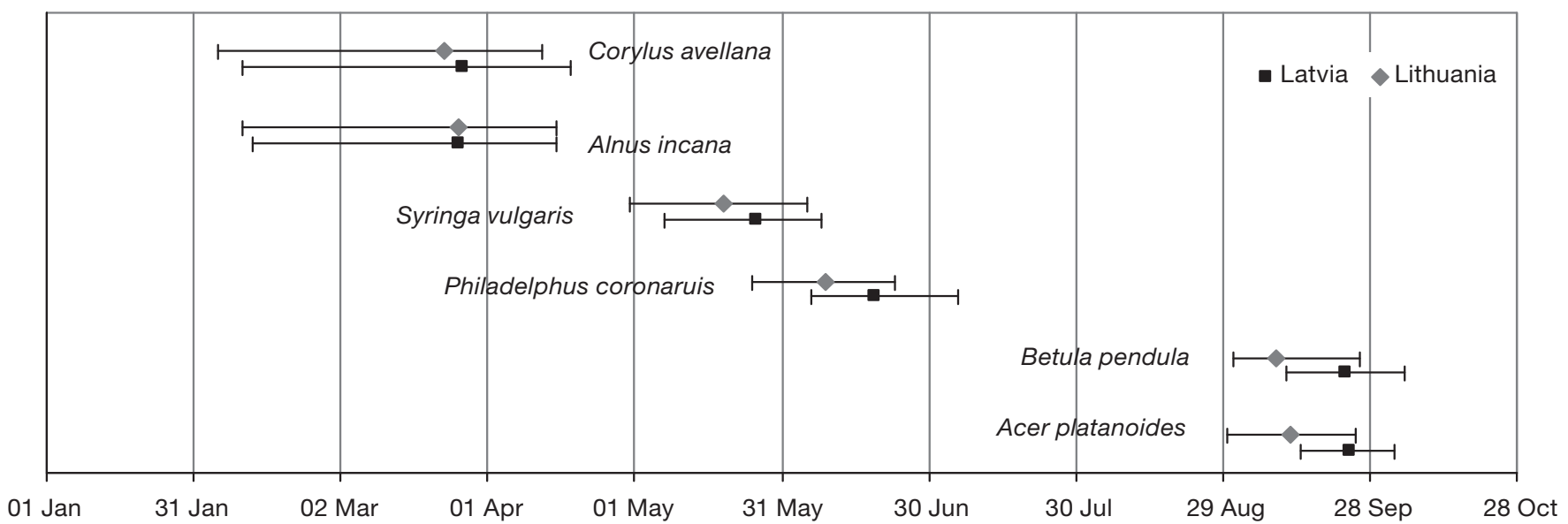

Fig. 2. Phenological calendar for the period 1971-2000 for Latvia and Lithuania. $y$-axis represents the sequence of phases. Phenophases are the beginning of flowering for spring and the beginning of leaf colouring for autumn

located just south of Latvia, European hazel started to flower $6 \mathrm{~d}$ earlier on average, and this phenological phase spread across the country within $8 \mathrm{~d}$ (20 to 27 March) (Fig. 2). The same process in Latvia took twice as long as in Lithuania (19 d, from 21 to 23 March in coastal areas until 8 April in Dagda, the easternmost station in Latvia). The flowering of grey alder, another spring indicator, started in both countries only 1 to $2 \mathrm{~d}$ after hazel and spread over the entire territory of both Lithuania and Latvia within 2 wk (21 to 24 March in coastal areas to 5 April in eastern Latvia). It was found that flowering of these spring season indicators started earlier on average in localities closer to the Baltic Sea: 4 to $6 \mathrm{~d}$ earlier at Silute (Lithuania) and 5 to $8 \mathrm{~d}$ earlier at Liepaja-Nica, Pope (Latvia). Annual variations in the dates of the beginning of hazel and alder flowering were very high in both Baltic countries (CV > $20 \%$ in some localities). The earliest flowering of hazel and alder began in 1989-1990 (January-February) (Fig. 3). The latest flowering of these plants was recorded in the second half of April. Late flowering was more frequent in the middle of the 1990s. Since the differences between the earliest and average dates are twice as great as those between the latest and average dates, negative anomalies are more common. From comparisons of spring, summer and autumn phenological phases for the selected species, it is evident that spring phases have larger variations. According to our

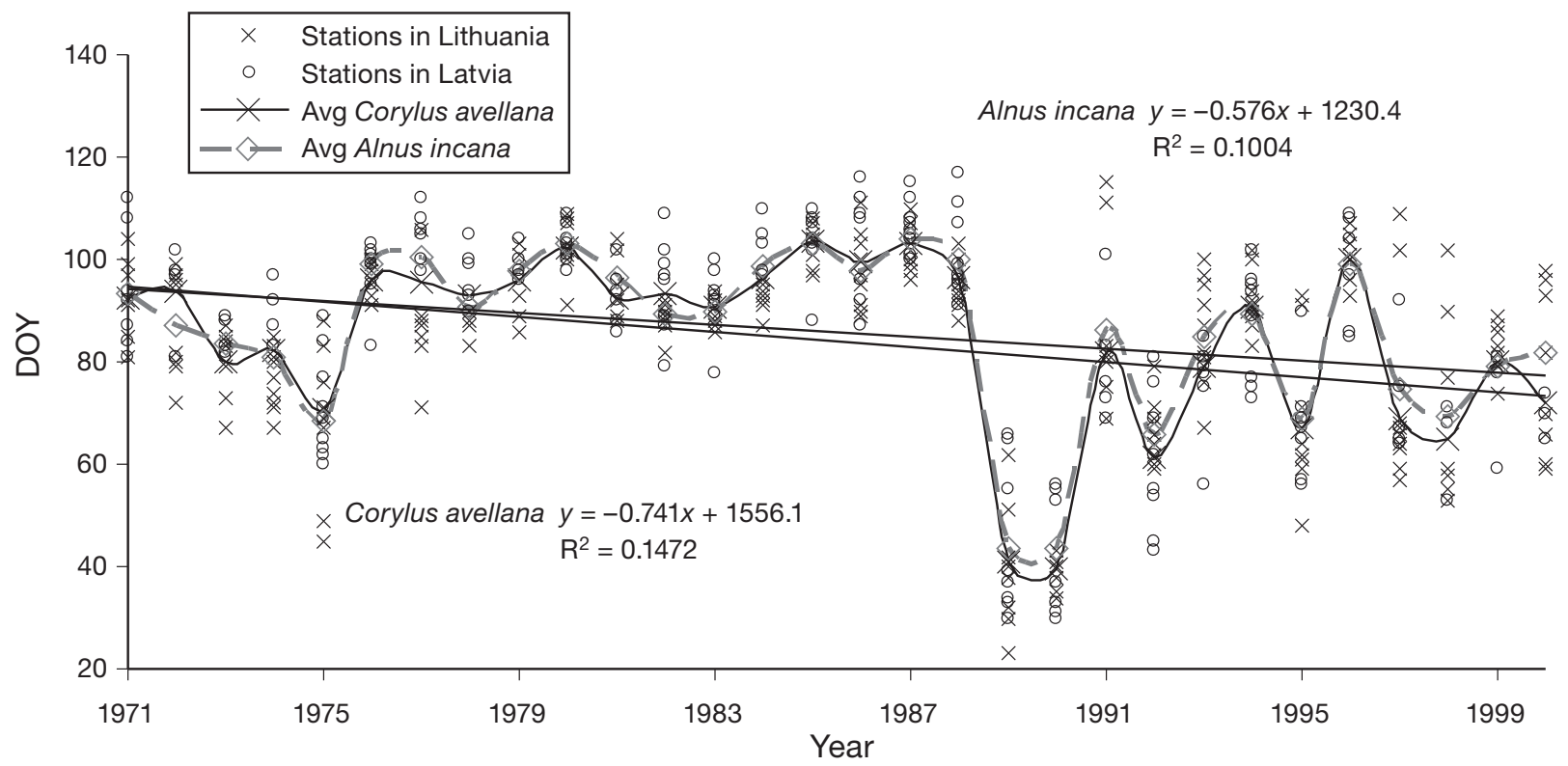

Fig. 3. Corylus avellana and Alnus incana. Trends in the beginning of flowering of European hazel C. avellana and grey alder A. incana (average data from 10 stations) 1971-2000 in Latvia and Lithuania. DOY: day of year 
data, the beginning of phenological spring spread from SW to NE by, on average, $4.5 \mathrm{~d}$ per $100 \mathrm{~km}$.

The beginning of flowering of the summer indicators sweet mock orange/false jasmine Philadelphus coronarius and common lilac Syringa vulgaris did not coincide. In both Baltic countries, lilac started flowering 3 wk earlier on average than sweet mock orange. Flowering of the spring season indicators (hazel and alder) and flowering of the summer season indicators (lilac and mock orange) started earlier in Lithuania than in Latvia (Fig. 2). Common lilac started to flower in Lithuania, on average, from 17 to 22 May but in Latvia from 24 to 30 May when this phenophase had already spread over the whole territory of Lithuania. The flowering of common lilac and sweet mock orange began earlier in the southern and central parts of the countries. In both countries, the flowering of sweet mock orange and common lilac started 4 to $6 \mathrm{~d}$ later in localities closer to the Baltic Sea. The flowering of common lilac spread over the whole territory of both Latvia and Lithuania within a $5 \mathrm{~d}$ period. The beginning of summer spread from south to north with a phenological gradient of $3.7 \mathrm{~d}$ per $100 \mathrm{~km}$.

Annual variation in the dates of the beginning of common lilac flowering was low $(<10 \%): 4.7$ to $5.9 \%$ in Lithuania and 5.6 to $7.0 \%$ in Latvia. Mean deviations of the earliest and latest dates from the average were almost equal but they were smaller than for species that started to flower early in spring. The earliest and latest dates of the beginning of common lilac flowering in Latvia and Lithuania occurred in different years; the earliest flowering at all phenological stations in Latvia was recorded in 1990, while in Lithuania it occurred 1 decade later in 2000. All of the latest dates of the beginning of common lilac flowering in Lithuania were in 1980, while in Latvia the latest dates were recorded in 1980 only in 2 locations (Atasiene-Barkava and Dagda); in other locations the latest dates were recorded in 1987 (Fig. 4).

Autumn, as indicated by the colouring of the leaves of Norway maple Acer platanoides and common birch Betula pendula, started in September; the dates of the recorded phenological phases were earlier in Lithuania. In Latvia, Norway maple and common birch leaves started colouring during the second half of September, but in Lithuania this occurred in the beginning of September, except at Papile. Papile is located in the northern part of Lithuania, and the colouring of Norway maple leaves started on 24 August and 20 August for birch leaves. The average latest colouring of Norway maple was recorded at Dobele on 26 September, whilst the average latest common birch leaf colouring was at Keturvalakiai on 5 October. Thus the duration of phenological phases of autumn indicators over the territories of both Baltic countries was about $4 \mathrm{wk}$, i.e. considerably longer than the periods of spring and summer events. The largest deviations from the average (earliest and latest dates) were recorded in different years (Fig. 5).

\subsection{Trends in phenological seasons}

The data for 1971-2000 show a tendency of annual advancement of the phenological phases for summer, autumn and spring indicators (Table 2). However, the

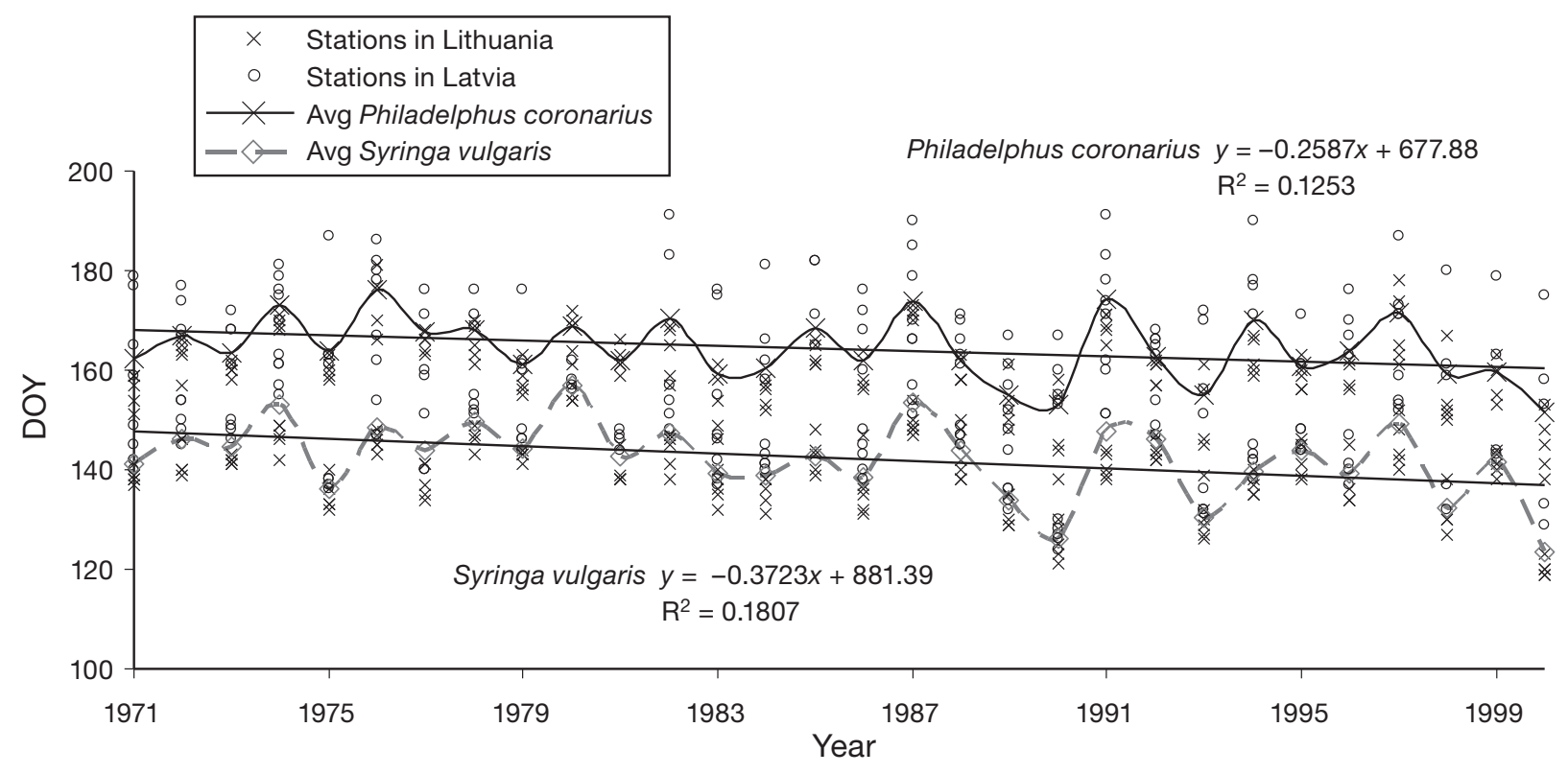

Fig. 4. Philadelphus coronarius and Syringa vulgaris. Trends in the beginning of flowering of sweet mock orange P. coronarius and common lilac $S$. vulgaris (average data from 10 stations) for the period 1971-2000 in Latvia and Lithuania. DOY: day of year 


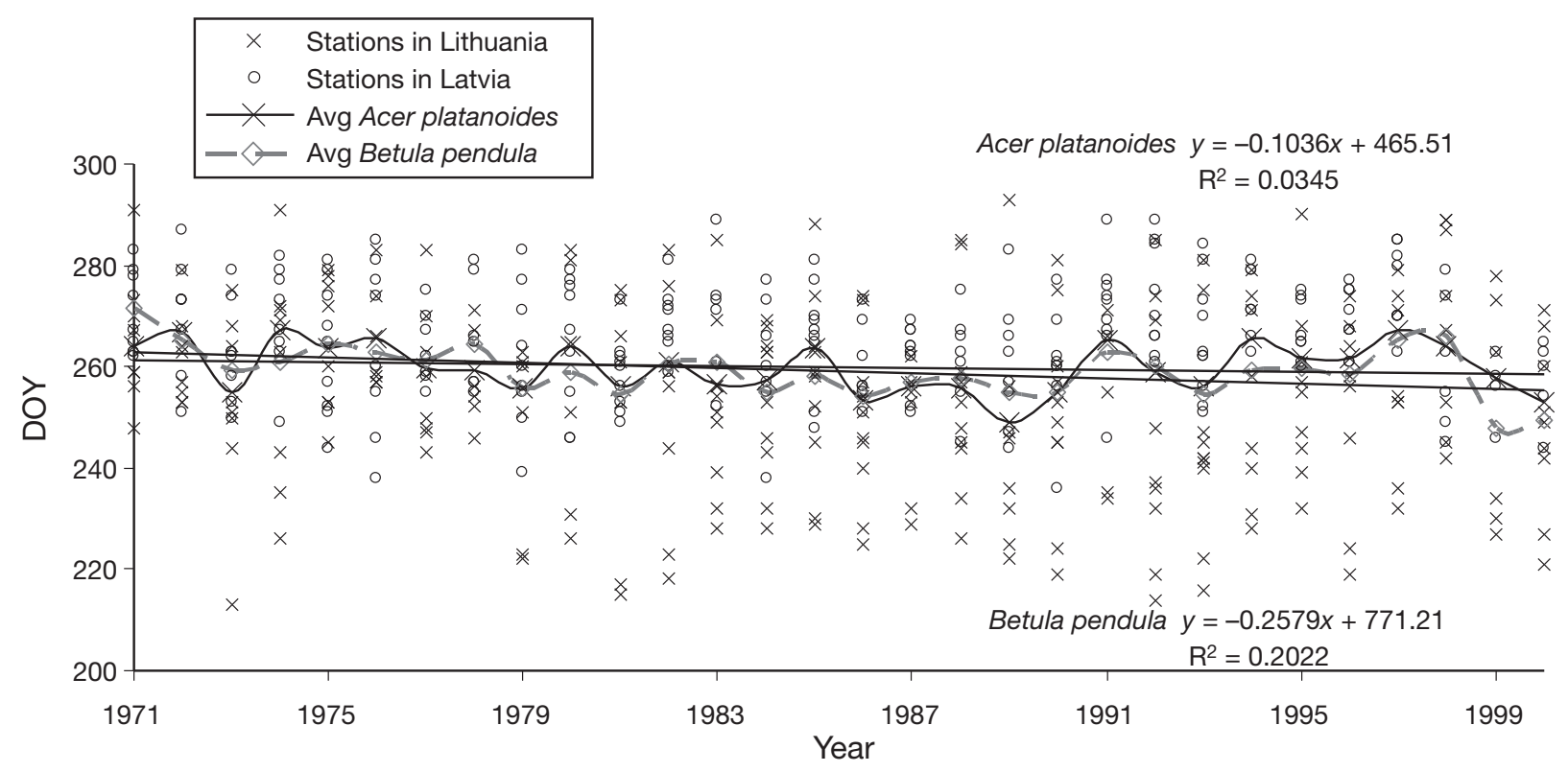

Fig. 5. Acer platanoides and Betula pendula. Trends in the beginning of leaf colouring of Norway maple Acer platanoides and common birch Betula pendula (average data from 10 stations) for the period 1971-2000 in Latvia and Lithuania. DOY: day of year

Table 2. Statistical parameters of the phenological seasons and phases in Latvia and Lithuania (1971-2000). Data for 'Onset of phenological phases' are mean \pm SE. DOY: day of year. Significant values $(M-K>1.65$ or $<-1.65$, with $p<0.05)$ are in bold

\begin{tabular}{|c|c|c|c|c|c|c|c|}
\hline $\begin{array}{l}\text { Season } \\
\text { and species }\end{array}$ & Station & Year $(\mathrm{N})$ & \multirow[t]{2}{*}{$\begin{array}{c}\text { Onset of phenological } \\
\text { phases (DOY) }\end{array}$} & \multirow[t]{2}{*}{ CV (\%) } & Slope & \multicolumn{2}{|c|}{ Mann-Kendall test } \\
\hline \multicolumn{6}{|l|}{ Spring } & & \\
\hline \multicolumn{8}{|l|}{ Corylus avellana } \\
\hline \multirow[t]{5}{*}{ Latvia } & Atasiene Barkava & 23 & $91 \pm 4$ & 21.30 & -1.11 & -1.14 & 0.13 \\
\hline & Dagda & 15 & $98 \pm 4.8$ & 18.80 & -0.63 & 0.10 & 0.46 \\
\hline & Dobele & 30 & $87 \pm 3.4$ & 21.30 & -0.76 & -1.58 & 0.06 \\
\hline & Liepaja Nica & 23 & $80 \pm 4.5$ & 27.10 & -0.95 & -1.51 & 0.07 \\
\hline & Pope & 27 & $83 \pm 4$ & 24.90 & -1.06 & -1.69 & 0.05 \\
\hline \multirow[t]{5}{*}{ Lithuania } & Traku Voke & 27 & $82 \pm 3.2$ & 20.60 & -0.91 & -1.82 & 0.04 \\
\hline & Akademija & 28 & $83 \pm 3.6$ & 22.80 & -0.68 & -1.68 & 0.05 \\
\hline & Silute & 29 & $78 \pm 4$ & 27.40 & -0.69 & -1.22 & 0.11 \\
\hline & Papile & 30 & $86 \pm 3.4$ & 21.40 & -0.12 & 0.63 & 0.27 \\
\hline & Keturvalakiai & 28 & $80 \pm 3.1$ & 20.60 & -0.48 & -0.36 & 0.36 \\
\hline \multicolumn{8}{|l|}{ Alnus incana } \\
\hline \multirow[t]{5}{*}{ Latvia } & Atasiene Barkava & 16 & $89 \pm 5.6$ & 25.10 & -1.34 & -1.76 & 0.04 \\
\hline & Dagda & 22 & $95 \pm 3.2$ & 15.90 & -0.52 & 0.14 & 0.44 \\
\hline & Dobele & 26 & $87 \pm 3.4$ & 20.20 & -0.49 & -0.55 & 0.29 \\
\hline & Liepaja Nica & 23 & $82 \pm 4.3$ & 25.10 & -1.47 & -2.70 & 0.00 \\
\hline & Pope & 26 & $83 \pm 4.1$ & 25.50 & -1.00 & -1.57 & 0.06 \\
\hline \multirow[t]{5}{*}{ Lithuania } & Traku Voke & 27 & $82 \pm 3.1$ & 19.80 & -0.85 & -1.65 & 0.05 \\
\hline & Akademija & 26 & $86 \pm 3.4$ & 20.10 & -0.69 & -1.63 & 0.05 \\
\hline & Silute & 26 & $80 \pm 4.1$ & 25.90 & -0.52 & -0.82 & 0.21 \\
\hline & Papile & 29 & $90 \pm 3.3$ & 20.00 & 0.17 & 1.32 & 0.09 \\
\hline & Keturvalakiai & 15 & $92 \pm 2.9$ & 12.30 & -0.10 & 0.20 & 0.42 \\
\hline \multirow{2}{*}{\multicolumn{8}{|c|}{$\begin{array}{l}\text { Summer } \\
\text { Syringa vulgaris }\end{array}$}} \\
\hline & & & & & & & \\
\hline \multirow[t]{5}{*}{ Latvia } & Atasiene Barkava & 27 & $145 \pm 1.6$ & 5.90 & -0.27 & -1.61 & 0.05 \\
\hline & Dagda & 22 & $145 \pm 1.7$ & 5.60 & -0.46 & -1.87 & 0.03 \\
\hline & Dobele & 27 & $144 \pm 1.6$ & 5.70 & -0.34 & -1.55 & 0.06 \\
\hline & Liepaja Nica & 22 & $145 \pm 2.2$ & 7.00 & -0.44 & -1.73 & 0.04 \\
\hline & Pope & 26 & $150 \pm 1.7$ & 5.90 & -0.17 & -1.20 & 0.12 \\
\hline
\end{tabular}


Table 2. (continued)

\begin{tabular}{|c|c|c|c|c|c|c|c|}
\hline $\begin{array}{l}\text { Season } \\
\text { and species }\end{array}$ & Station & Year $(\mathrm{N})$ & \multirow[t]{2}{*}{$\begin{array}{c}\text { Onset of phenological } \\
\text { phases (DOY) }\end{array}$} & \multirow[t]{2}{*}{$\mathrm{CV}(\%)$} & \multirow[t]{2}{*}{ Slope } & \multicolumn{2}{|c|}{ Mann-Kendall tes } \\
\hline \multicolumn{5}{|l|}{ Summer } & & & \\
\hline \multicolumn{8}{|l|}{ Syringa vulgaris } \\
\hline \multirow[t]{5}{*}{ Lithuania } & Traku Voke & 27 & $137 \pm 1.5$ & 5.70 & -0.40 & -1.91 & 0.03 \\
\hline & Akademija & 28 & $138 \pm 1.5$ & 5.90 & -0.36 & -1.96 & 0.03 \\
\hline & Silute & 30 & $138 \pm 1.4$ & 5.40 & -0.40 & -2.34 & 0.01 \\
\hline & Papile & 30 & $142 \pm 1.2$ & 4.70 & -0.16 & -0.65 & 0.26 \\
\hline & Keturvalakiai & 30 & $141 \pm 1.4$ & 5.50 & -0.38 & -2.01 & 0.02 \\
\hline \multicolumn{8}{|l|}{ Philadelphus coronarius } \\
\hline \multirow[t]{5}{*}{ Latvia } & Atasiene Barkava & 27 & $169 \pm 1.7$ & 5.20 & -0.45 & -2.79 & 0.00 \\
\hline & Dagda & 17 & $164 \pm 2$ & 5.10 & -0.52 & -1.08 & 0.14 \\
\hline & Dobele & 19 & $165 \pm 2.1$ & 5.50 & -0.20 & -0.77 & 0.22 \\
\hline & Liepaja Nica & 23 & $173 \pm 2.1$ & 5.90 & 0.39 & 1.61 & 0.05 \\
\hline & Pope & 23 & $176 \pm 1.4$ & 3.80 & -0.25 & -1.25 & 0.11 \\
\hline \multirow[t]{5}{*}{ Lithuania } & Traku Voke & 30 & $159 \pm 1.6$ & 5.40 & -0.45 & -2.40 & 0.01 \\
\hline & Akademija & 30 & $159 \pm 1.6$ & 5.40 & -0.41 & -2.13 & 0.02 \\
\hline & Silute & 30 & $159 \pm 1.7$ & 5.80 & -0.50 & -2.85 & 0.00 \\
\hline & Papile & 30 & $164 \pm 1$ & 3.50 & -0.12 & -0.86 & 0.20 \\
\hline & Keturvalakiai & 30 & $160 \pm 1.4$ & 4.70 & -0.11 & -0.32 & 0.37 \\
\hline \multicolumn{8}{|l|}{ Autumn } \\
\hline \multicolumn{8}{|l|}{ Acer platanoides } \\
\hline \multirow[t]{5}{*}{ Latvia } & Atasiene Barkava & 27 & $262 \pm 1.8$ & 3.50 & 0.31 & 1.42 & 0.08 \\
\hline & Dagda & 19 & $267 \pm 1.7$ & 2.80 & -0.63 & -2.04 & 0.02 \\
\hline & Dobele & 12 & $269 \pm 3.3$ & 4.30 & 0.21 & -0.21 & 0.42 \\
\hline & Liepaja Nica & 23 & $262 \pm 1.1$ & 2.00 & 0.04 & 0.43 & 0.34 \\
\hline & Pope & 24 & $267 \pm 1.3$ & 2.40 & -0.03 & -0.55 & 0.29 \\
\hline \multirow[t]{5}{*}{ Lithuania } & Traku Voke & 24 & $256 \pm 1.4$ & 2.70 & -0.39 & -2.07 & 0.02 \\
\hline & Akademija & 25 & $255 \pm 2.8$ & 5.50 & -0.57 & -1.83 & 0.03 \\
\hline & Silute & 18 & $262 \pm 1.6$ & 2.60 & 0.34 & 1.10 & 0.14 \\
\hline & Papile & 30 & $236 \pm 2.5$ & 5.70 & -0.56 & -2.11 & 0.02 \\
\hline & Keturvalakiai & 27 & $273 \pm 2.4$ & 4.70 & 0.18 & 1.24 & 0.11 \\
\hline \multicolumn{8}{|l|}{ Betula pendula } \\
\hline \multirow[t]{6}{*}{ Latvia } & Atasiene Barkava & 27 & $265 \pm 1.8$ & 3.50 & 0.40 & 1.54 & 0.06 \\
\hline & Dagda & 19 & $276 \pm 1.7$ & 2.80 & -0.27 & -2.22 & 0.01 \\
\hline & Dobele & 12 & $278 \pm 3.3$ & 4.30 & 0.05 & 0.27 & 0.39 \\
\hline & Liepaja Nica & 23 & $254 \pm 1.1$ & 2.00 & -0.24 & -1.39 & 0.08 \\
\hline & Pope & 24 & $260 \pm 1.3$ & 2.40 & 0.33 & 1.67 & 0.05 \\
\hline & Traku Voke & 22 & $253 \pm 1.5$ & 2.70 & -0.47 & -1.67 & 0.05 \\
\hline \multirow{4}{*}{ Lithuania } & Akademija & 24 & $250 \pm 3$ & 5.90 & -0.53 & -2.22 & 0.01 \\
\hline & Silute & 18 & $247 \pm 2.5$ & 4.20 & -0.80 & -2.31 & 0.01 \\
\hline & Papile & 30 & $232 \pm 2.6$ & 6.20 & -0.38 & -0.75 & 0.23 \\
\hline & Keturvalakiai & 28 & $278 \pm 1.6$ & 3.00 & 0.04 & -0.04 & 0.48 \\
\hline
\end{tabular}

advancement of dates of the beginning of phenological phases is more marked in plants starting to flower in the phenological summer; in 11 of 20 cases the trend is statistically significant $(\mathrm{M}-\mathrm{K}<-1.65, \mathrm{p}<0.05$, and the mean slope for phenological summer is -0.30 $(-0.11$ to -0.52$)$. The beginning of flowering of summer indicators advanced by 3 to $15 \mathrm{~d}$ during the study period.

During the last $30 \mathrm{yr}$, the flowering of European hazel in Lithuania advanced by 3.5 to $27.4 \mathrm{~d}(-0.1$ to $-0.9 \mathrm{~d}$ per year) and by 18.9 to $33.3 \mathrm{~d}$ ( -0.6 to $-1.1 \mathrm{~d}$ per year) in Latvia; alder has advanced by 3 to $25.5 \mathrm{~d}$ in Lithuania and 14.6 to $44 \mathrm{~d}$ in Latvia.

The present study also confirms that Norway maple and birch leaf colouring in the latest years tended to have an earlier timing; in 8 of 20 cases the trend was statistically significant and the mean slope for phenological autumn was -0.15 (-0.8 to 0.4) (Table 2).

During the last $10 \mathrm{yr}$ of the study period, the onset of phenological autumn occurred earlier than average in $50 \%$ of cases. From 1990 onwards, 9 out of 10 years saw spring phases recorded earlier than the 30-yr average. The earliest summer onset values were recorded in 6 of the last $10 \mathrm{yr}$ of the study period.

During all periods there was little influence of the distance from the sea on the trends in onset of phenological phases in summer, spring or autumn.

Table 3 shows recorded changes in phenological phases over 15 yr periods: 1971-1985 and 1986-2000. According to mean values, all species' phases observed during 1986-2000 had an earlier onset time than in the period 1971-1985. 
Table 3. Phenological phase means over 15-yr periods (average data from 10 stations). Data are dates (dd.mm)

\begin{tabular}{|c|c|c|}
\hline Phase (code) and plant & $1971-1985$ & $1986-2000$ \\
\hline \multicolumn{3}{|c|}{ Beginning of flowering (BBCH61) } \\
\hline Alnus incana & 01.04 & 22.03 \\
\hline Corylus avellana & 01.04 & 19.03 \\
\hline Syringa vulgaris & 25.05 & 19.05 \\
\hline Philadelphus coronarius & 15.06 & 11.06 \\
\hline \multicolumn{3}{|l|}{ Leaf colouring (BВCH92) } \\
\hline Betula pendula & 18.09 & 14.09 \\
\hline Acer platanoides & 18.09 & 16.09 \\
\hline
\end{tabular}

\subsection{Growing season}

Within the study period, the average duration of the growing season, defined as the time between leaf onset and leaf colouring for birch Betula pendula, was $138 \mathrm{~d}$. The shortest average growing season on record was $112 \mathrm{~d}$ in Papile (Lithuania), and the longest $157 \mathrm{~d}$ in Dagda (Latvia) and Keturvalakiai (Lithuania).

The average growing season for birch started on 1 May in the southern part of Lithuania and on 7 May in Pope, the northernmost phenological station. The end dates of the growing season varied from 20 August (Papile) to 5 October (Dagda, Keturvalakiai). The earliest dates of leafing (the beginning of the growing season) were recorded in 1990, when the growing season for birch started on average $18 \mathrm{~d}$ earlier (Fig. 6). The latest dates were recorded in 1980 (11 d later then average).

The shortest growing season at an individual station, Papile (Lithuania), was only 84 d in 1981 and the longest was 187 d in Keturvalakiai (Lithuania) in 1989. The shortest growing season (123 d) on average (data from 10 stations) was observed in 1979 and is in agreement with phenological observations for all European countries. The longest growing season (153 d) on average was observed in 1998.
As seen in Fig. 6, the trend in birch leafing - the beginning of the season - was statistically significant and negative ( $\mathrm{r}=-0.27$ to -0.55$)$, which is confirmed by the results of the Mann-Kendall test $(\mathrm{M}-\mathrm{K} \leq-1.65)$. The trend for the end date of the growing season was negative, yet it was statistically significant only for 4 out of 10 stations.

Within the study period, the beginning of the growing season advanced by 6.4 to $15.4 \mathrm{~d}$ (on average $-4.0 \mathrm{~d}$ per decade). For the most part, early dates have prevailed since the end of the 1980s. It is also noteworthy that the trend of the end date of the growing season was negative for 6 stations (phenological autumn has been observed 8.2 to $23.9 \mathrm{~d}$ earlier); leaf colouring, which marked the end of the period, occurred on average $2 \mathrm{~d}$ earlier over the 31-yr period. Examining the long-term time series of the beginning and end dates of the growing season showed that the growing season shifted to earlier dates in both spring and autumn. Overall, the length of the season was extended by an average of $7 \mathrm{~d}$, due to an earlier start.

\subsection{Influencing factors}

Three climate parameters - temperature, precipitation and the $\mathrm{NAO}_{\text {Dec-Feb }}$ index - were chosen for the study of influencing factors on phenological phases.

The strongest correlation was observed between the average air temperature of the preceding month and the onset of the phenological phase (Table 4). The correlation coefficient between temperature and the onset of the spring and summer phases varied from $\mathrm{r}=-0.55$ to -0.82 . The value of the associated correlation coefficient of the autumn phase was positive (with individual exceptions) and varied from $r=-0.11$ to 0.30 with the average temperatures of the previous 3 mo.

Concerning rainfall data, they showed a negative correlation with the spring phases $\left(\mathrm{r}_{\text {average }}=-0.26\right)$. February precipitation correlated well $(\mathrm{r}=\sim-0.50)$ with the flowering of grey alder and hazel in March.

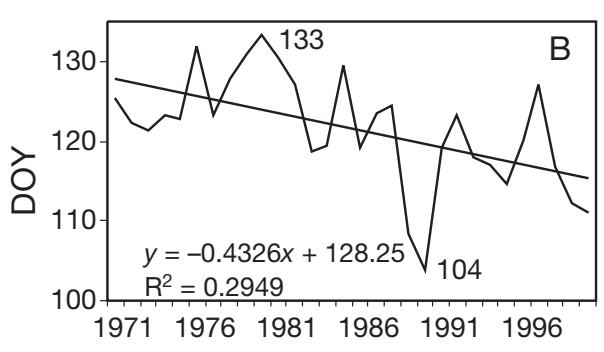

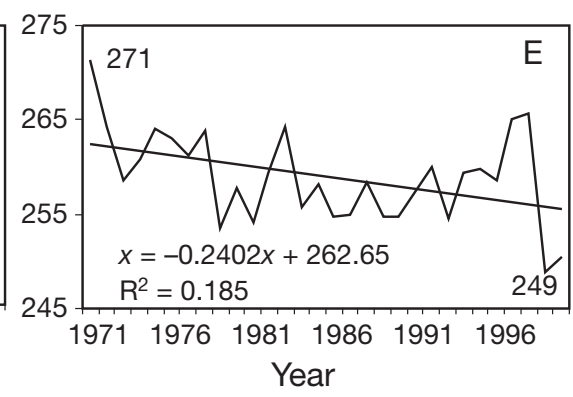

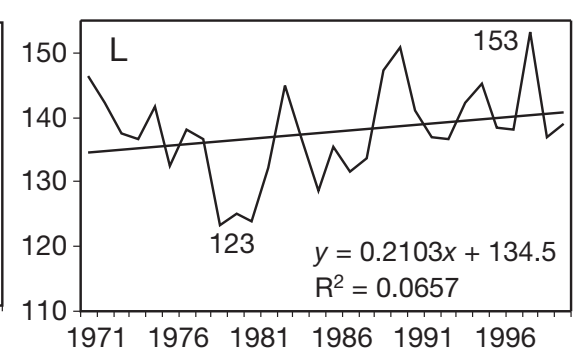

Fig. 6. Betula pendula. Trends in the average (data from 10 stations) beginning (B), end (E) and length (L) of the growing season for common birch $B$. pendula for the period 1971-2000. DOY: day of year 


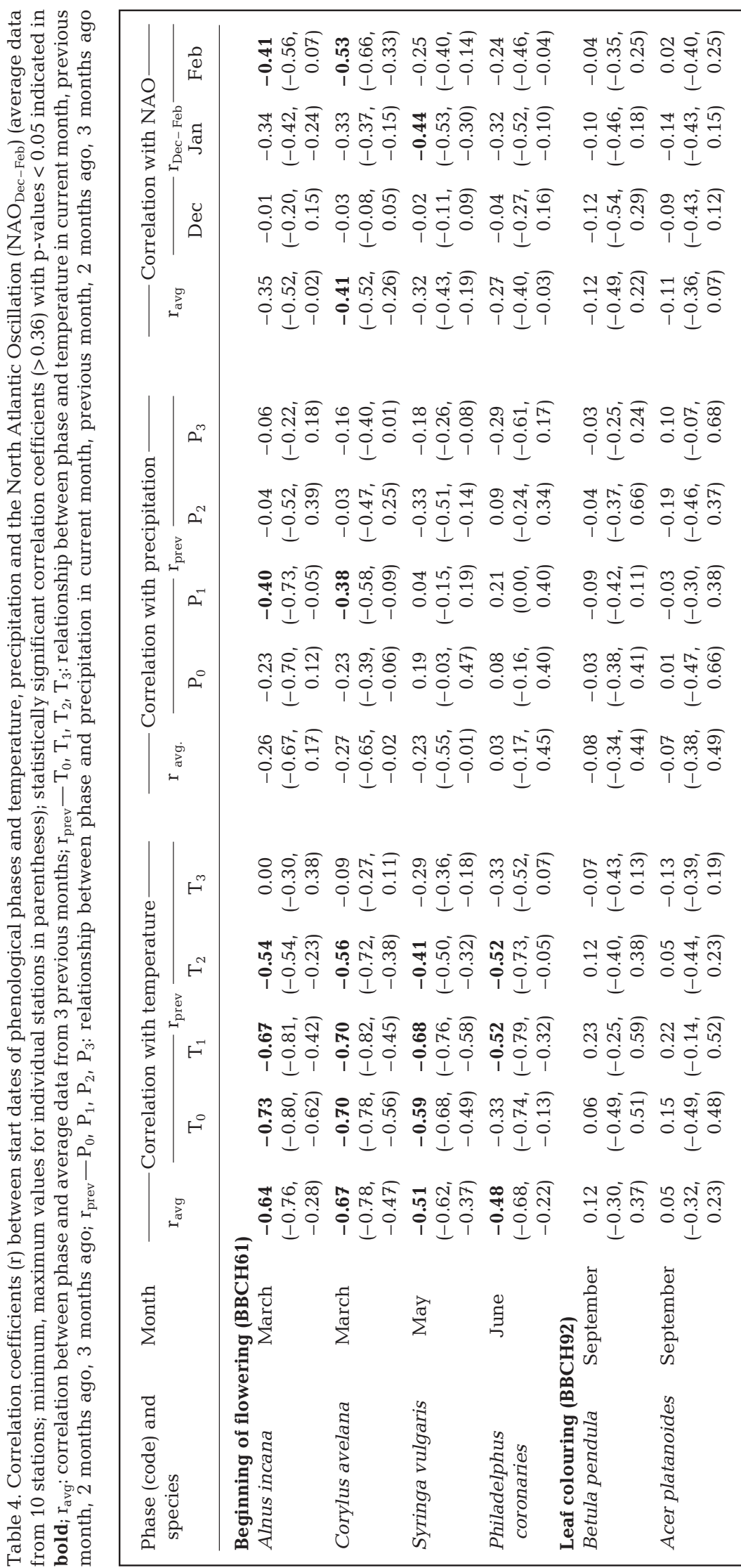

Overall, the NAO correlated well with the phenological anomalies. In analysing the relationship between the NAO and the onset of the phases, it was noticed that the connection with the spring and summer phases was stronger than that with autumn phases. The $\mathrm{NAO}_{\mathrm{Feb}}$ relationship was slightly stronger $\left(\mathrm{r}_{\text {average }}=-0.41\right.$ to -0.53$)$ in comparison with $\mathrm{NAO}_{\text {Dec-Feb, }}$ where $\mathrm{r}$ varied from -0.02 to -0.52 .

\section{DISCUSSION}

As established in the majority of studies undertaken in Europe, the Latvian and Lithuanian data analysis for the 1971-2000 period shows that a significant negative trend existed in the onset dates of spring and summer phases. In addition, the spring phases had a wider variation in onset dates than summer or autumn phases and spring deviated considerably (up to $40 \mathrm{~d}$ ) from the longterm average.

Data show that the earliest spring flowering plants were very sensitive to climate change. Unusually warm winters influenced large negative deviations from the average as in 1989 (the highest January temperatures for the 1971-2000 period at all studied stations) and 1990 (the highest February and March temperatures for the 19712000 period at all studied stations). In those years the flowering of hazel and grey alder was recorded in January and February, i.e. $\sim 42 \mathrm{~d}$ earlier than the observed average recorded. The present study shows that phenophase onset times changed considerably over the last decade of the study period. For example, since the 1990 spring phase, 9 out of 10 years have seen an earlier onset than the long-term average.

In contrast to what has been recorded in the most of Europe, the phenological autumn tended to start earlier in Latvia and Lithuania. This is consistent with the findings of studies by Chmielewski \& Rötzer (2001) and Shutova et al. (2006), who carried out their research in the International Phenological Gardens and in Kola Peninsula, respectively. Shu- 
tova et al. (2006) suggested that earlier yellowing in the Kola Peninsula was closely associated with a trend towards an earlier decrease in autumn air temperature within the study period, indicating that this environmental factor was important for autumn phenophases. Chmielewski \& Rötzer (2001) noted that growing seasons in the Baltic region ended $0.1 \mathrm{~d}$ per 10 yr earlier, explained by Estonian phenologists (Ahas \& Aasa 2006) as the influence of the Baltic Sea. Bukantis (1995) found that the most obvious influence of the Baltic Sea on climate, depending on land relief, was in the coastal belt about 30 to $100 \mathrm{~km}$ wide.

Accordingly, analysing the long-term temperature time series in Europe (Klein Tank \& Können 2003) found an increase in the number of cold days in autumn during the period 1946-1999. We suggest that the observed trend towards earlier autumn phenological phases was associated with the increase in cold days that cannot be derived from average monthly temperatures (i.e. the extreme temperatures values are not shown in the monthly mean values).

The length of the growing season (defined here as the period between birch leafing and colouring) in the studied areas increased by $7 \mathrm{~d}$, mainly through an earlier onset of the spring phase. Similar to the observations in Europe (Chmielewski \& Rotzer 2002), the earliest dates of leafing (the beginning of the growing season) in Latvia and Lithuania were recorded in 1990, when the growing season for birch started $20 \mathrm{~d}$ earlier, on average. The shortest growing season was observed in 1979, which was a cold year across the whole of Europe.

To provide a comparison with the work of other authors (D'Odorico et al. 2002, Menzel 2003, Aasa et al. 2004, Jaagus 2006), we examined the correlation between the phenological data and the average air temperature and precipitation of the present and the 3 preceding months at each station.

We found a strong correlation between the onset of a phase and the average air temperature of the preceding month. The strongest correlation among the spring phases was observed between the onset of the phase in March and the average air temperature in February. It should be noted that another very significant relationship was found between March air temperature and the onset of the phase in March. During the summer phase the strongest correlations were between the onset of lilac flowering in May and April air temperature and between the onset of sweet mock orange flowering in June and May air temperature. The relationship between the spring and summer phases is inversely related because a higher air temperature of the preceding month causes earlier onset of the phase.

The relationships between precipitation and phenological phases were generally weak. Among them the strongest negative correlations were found between the amount of precipitation in February and flowering of Corylus avellana (5 of 10 coefficients were statistically significant) and Alnus incana (7 of 10 coefficients were statistically significant) in March. This might be associated with the character of snow accumulation, which may delay the onset of the growing season.

Overall, the NAO correlated rather well with the phenological anomalies of particular seasons. At the same time we found stronger correlation with NAO in winter months in Latvia, which could be explained by the dominance of northern Europe circulation over Latvia and central Europe circulation over Lithuania (Jaak et al. unpubl. data).

The results indicate that, compared to summer, phenological spring more often deviates from the longterm average. For example, the 1989-1990 phenological spring started $43 \mathrm{~d}$ earlier and larger NAO positive values were detected during those years. The 1990 phenological summer, the greatest negative deviation, started 2 wk earlier. In turn, both negative deviations, earlier onset of the spring phase and summer phase observed after the 1980s, correlated well with positive NAO values. Positive deviations, i.e. later onset of phase, recorded in the 1980s related to negative values of the NAO.

No correlations with NAO were observed in the autumn phases, with the exception of the colouring of birch leaves (Latvian data) and the NAO of the 3 preceding months. One possible explanation could be the weakening of the NAO and other types of circulation during the autumn period (Jaagus 2006). Concerning circulation characteristics and types in autumn, Draveniece (2007) verified that beginning in early autumn (end of August) the equator-pole temperature gradient gradually gets stronger and, as a result, the westerly circulation starts strengthening and a transition to a winter circulation occurs.

Further studies on the relationship between phenophases and the changes in temperature and precipitation should be carried out by using daily extremes of temperature and precipitation values, which could provide new insights in phenological variation on a and temporal spatial scale.

Acknowledgements. Financial support from the Agency for International Science and Technology Development Programmes in Lithuania and European Social Fund (Project No. 2004/0001/VPD1/ESF/PIAA/04/NP/3.2.3.2./0001/0001/0063) is gratefully acknowledged.

\section{LITERATURE CITED}

Aasa A, Jaagus J, Ahas R, Sepp M (2004) The influence of atmospheric circulation on plant phenological phases in central and eastern Europe. Int J Climatol 24:1551-1564 
Ahas R (1999) Long-term phyto-, ornitho- and ichthyophenological time-series analysis in Estonia. Int $\mathrm{J}$ Biometeorol 42:119-124

Ahas R, Aasa A (2006) The effects of climate change on the phenology of selected Estonian plant, bird and fish populations. Int J Biometeorol 51:17-26

Ahas R, Aasa A, Menzel A, Fedotova VG, Scheifinger H (2002) Changes in European spring phenology. Int J Climatol 22: 1727-1738

Beaubien EG, Freeland HJ (2000) Spring phenology trends in Alberta, Canada: links to ocean temperature. Int J Biometeorol 44:53-59

Bogaert J, Zhou L, Tucker CJ, Myneni RB, Ceulemans R (2002) Evidence for a persistent and extensive greening trend in Eurasia inferred from satellite vegetation index data. J Geophys Res 107(D11):4119, doi:10.1029/2001JD001075

Bradley NL, Leopold AC, Ross J, Huffaker W (1999) Phenological changes reflects climate change in Wisconsin. Proc Natl Acad Sci USA 96:9701-9704

Bukantis A (1995) Extreme winters in the Baltic Sea area. Geografijos Metraštis 28:178-194

Chmielewski FM, Rötzer T (2001) Response of tree phenology to climate change across Europe. Agric Meteorol 108: 101-112

Chmielewski FM, Rötzer T (2002) Annual and spatial variability of the beginning of growing season in Europe in relation to air temperature changes. Clim Res 19:257-264

Chuine I, Yiou P, Viovy N, Seguin B, Daux V, Le Roy Ladurie E (2004) Grape ripening as a past climate indicator. Nature 432:289-290

D'Odorico P, Yoo JC, Jaeger S (2002) Changing seasons: an effect of the North Atlantic Oscillation? J Clim 15:435-445

Dospehov BA (1973) Методика полевого опыта (Field work methodology). Kolos, Moscow (in Russian)

Draveniece A (2007) Oceanic and continental air masses over Latvia. Latv Vegetacija 14:1-135 (in Latvian with English Abstract)

Grisule G, Briede A (2007) Phenological time series in Latvia as climate change indicators. In: Klavins M (ed) Climate

Submitted: June 30, 2008; Accepted: March 19, 2009 change in Latvia. University of Latvia, Riga

Harrington R, Woiwod I, Sparks T (1999) Climate change and trophic interactions. Trends Ecol Evol 14:146-150

Jaagus J (2006) Climatic changes in Estonia during the second half of the 20th century in relationship with changes in large-scale atmospheric circulation. Theor Appl Climatol 83:77-88

Klein Tank AMG, Können GP (2003) Trends in indices of daily temperature and precipitation extremes in Europe, 1946-1999. J Clim 16:3665-3680

Kulienè L, Tomkus J (1990) Bendroji fenoloǵija (General phenology). Mokslas, Vilnius (in Lithuanian with English Abstract)

Libiseller C, Grimvall A (2002) Performance of partial Mann Kendall tests for trend detection in the presence of covariates. Environmetrics 13:71-84

Linderholm HW (2006) Growing season changes in the last century. Agric Meteorol 137:1-14

McKnight TL, Hess D (2004) Physical geography: a landscape appreciation. Prentice Hall, Upper Saddle River, NJ

Meier U (ed) (1997) Growth stages of mono- and dicotyledonous plants. BBCH Monograph. Federal Biological Research Centre for Agriculture and Forestry, Blackwell Wissenschafts-Verlag, Berlin

Menzel A (2000) Trends in phenological phases in Europe between 1951 and 1996. Int J Biometeorol 44:76-81

> Menzel A (2003) Plant phenological anomalies in Germany and their relation to air temperature and NAO. Clim Change 57:243-263

Romanovskaja D, Bakšienè E (2007) Influence of a thermal mode on the seasonal phenological phenomena in Lithuania. Ekologija 1:15-20

Root TL, Price JT, Hall KR, Schneider SH, Rosenzweig C (2003) Fingerprints of global warming on wild animals and plants. Nature 421:57-60

Shutova E, Wielgolaski F, Karlsen S, Makarova O and others (2006) Growing seasons of Nordic mountain birch in northernmost Europe as indicated by long-term field studies and analyses of satellite images. Int J Biometeorol 51:155-166

Proofs received from author(s): August 3, 2009 